\title{
Efektivitas Program Duta Hand Hygiene di Rumah Sakit Islam Jemursari Surabaya
}

\author{
Effectiveness of Hand Hygiene Ambassador Program \\ in Islamic Hospital Jemursari Surabaya
}

\author{
Herlina Novita \\ Departemen Administrasi dan Kebijakan Kesehatan, Fakultas Kesehatan Masyarakat, Universitas \\ Airlangga, Surabaya, Indonesia \\ Email: herlina.novita-2014@fkm.unair.ac.id
}

\begin{abstract}
Background: Infections related to health services may affect the safety of patient, health worker and visitor safety in health services including in the hospitals. Islamic Jemursari Hospital Surabaya launches Hand Hygiene Ambassador program in order to improve staffs'obedience of hand hygiene in the hospital. Purpose: This research aimed to analyze the impact of Hand Hygiene Ambassador program on staffs'obedience of the five moments hand hygiene and describe the health promotion strategy based on WHO multimodal hand hygiene improvement strategy in the hospital. Method: This research was conducted at Islamic Hospital Jemursari Surabaya by collecting secondary data from monthly report of Infection Prevention and Control Committee related to hand hygiene monitoring, interview and observation. Paired t-test technique was used to analyse the data. Result: The staf fs'obedience of five moment hand hygiene increased after the implemetation of hand hygiene ambassador program in the hospital. Based on the result of statistical paired t-test, there is difference of hand hygiene obedience at moment two to moment five. The result of statistical test as a whole showed significant result 0.000001 which indicated that there is a difference of obedience between before and during the Hand Hygiene Ambassador program implemented. Conclusion: this program was an effective strategy and its implementation supported by the WHO multimodal hand hygiene improvement strategy. The key component of the strategy are system change, training or education, evaluation and feedback, reminder in the workplace and institutional safety climate.
\end{abstract}

Keyword: Hand Hygiene Ambassador Program, obedience, Effectiveness, hospital

\begin{abstract}
ABSTRAK
Latar Belakang: Infeksi terkait pelayanan kesehatan dapat mempengaruhi keselamatan pasien, petugas kesehatan dan pengunjung di pelayanan kesehatan termasuk rumah sakit. Rumah Sakit Islam Jemursari Surabaya melaksanakan program Duta Hand Hygiene salah satu tujuannya yaitu untuk meningkatkan kepatuhan hand hygiene petugas rumah sakit. Tujuan: Tujuan penelitian ini untuk mengetahui efektivitas dengan menguji pengaruh pelaksanaan program Duta Hand Hygiene terhadap kepatuhan five moment hand hygiene petugas dan menjelaskan strategi promosi kesehatan berdasarkan startegi multimodal WHO dalam peningkatan hand hygiene di rumah sakit. Metode: Penelitian ini dilakukan di Rumah Sakit Islam Jemursari dengan metode pengumpulan data sekunder dari laporan bulanan Komite Pencegahan dan Pengendalian Infeksi terkait monitoring kepatuhan hand hygiene, wawancara dan observasi. Teknik analisa data yang digunakan yaitu kuantitatif yang diuji menggunakan uji-T berpasangan. Hasil: Kepatuhan five moment hand hygiene petugas meningkat setelah diberlakukannya program duta hand hygiene di rumah sakit. Berdasarkan hasil uji statisktik yaitu uji-T berpasangan didapat bahwa terdapat perbedaan yang signifikan kepatuhan hand hygiene petugas pada momen dua sampai momen lima dan hasil uji statistik secara keseluruhan menunjukan hasil yang signifikan sebesar 0.000001. Hasil penelitian ini menunjukkan ada perbedaan kepatuhan sebelum dilaksanakan program Duta Hand Hygiene dan selama program Duta hand hygiene berlangsung. Kesimpulan: Program ini efektif dilakukan serta pelaksanaannya didukung
\end{abstract}


oleh strategi multimodal WHO untuk peningkatan praktik hand hygiene antara lain perubahan sistem, pelatihan atau edukasi, evaluasi dan umpan balik, pengingat di tempat kerja dan iklim institusional yang aman.

Kata Kunci : Program Duta Hand Hygiene, Kepatuhan, efektivitas, rumah sakit

\section{PENDAHULUAN}

Penularan infeksi dapat terjadi antara pasien, petugas pelayanan kesehatan dan pengunjung. Praktik hand hygiene dengan benar dapat mencegah penyakit atau infeksi baik dari petugas kesehatan kepada pasien, dari pasien kepada petugas kesehatan atau kepada pengunjung. Petugas kesehatan berisiko tertular infeksi di tempat pelayanan kesehatan karena proses dalam pekerjaannya. Infeksi terkait pelayanan kesehatan adalah masalah yang besar bagi keselamatan pasien yang dampaknya dapat memperpanjang lama perawatan, kecacatan jangka panjang, meningkatkan resistensi dari mikroorganisme terhadap antimikroba, menambah beban keuangan yang semakin besar, dan menyebabkan kematian (WHO, 2009a). Infeksi terkait pelayanan kesehatan meningkatkan biaya kesehatan karena penambahan antimicrobial treatment dan memperpanjang perawatan pasien dalam rumah sakit atau length of stay (Shahida et al., 2016). Transisi infeksi melalui tangan dari petugas kesehatan merupakan penyebab paling umum penularan infeksi terkait pelayanan kesehatan yang dapat dicegah melalui praktik cuci tangan yang benar (Blackwell, 2017).

Infeksi terkait Pelayanan Kesehatan (Health Care Associated Infections) adalah infeksi yang terjadi pada pasien selama perawatan di rumah sakit dan fasilitas pelayanan kesehatan lainnya dimana ketika masuk tidak ada infeksi dan tidak dalam masa inkubasi, termasuk infeksi dalam rumah sakit tapi muncul setelah pasien pulang, juga infeksi karena pekerjaan pada petugas rumah sakit dan tenaga kesehatan terkait proses pelayanan kesehatan di fasilitas pelayanan kesehatan (Kementerian Kesehatan RI, 2017). WHO mengartikan infeksi yaitu suatu keadaan yang disebabkan oleh mikroorganisme patogen seperti bakteri, virus, parasit atau jamur yang dapat menyebabkan penyakit secara langsung atau tidak langsung dari satu orang ke orang lain. Pencegahan dan Pengendalian Infeksi merupakan upaya untuk mencegah dan meminimalkan terjadinya infeksi pada pasien, petugas, pengunjung, dan masyarakat sekitar fasilitas pelayanan kesehatan dan setiap pelayanan kesehatan harus melaksanakan pencegahan dan pengendalian Infeksi.

Duta hand hygiene berfungsi sebagai promosi kesehatan terkait hand hygiene di lingkungan rumah sakit yang sasarannya seluruh masyarakat di lingkungan rumah sakit baik petugas, pasien, dan keluarga pasien atau pengunjung. Pengertian promosi kesehatan menurut WHO adalah proses memampukan seseorang yang bertujuan untuk meningkatkan kontrol dan derajat kesehatan. Promosi kesehatan adalah semua kegiatan yang bertujuan untuk melindungi atau meningkatkan kesehatan (Kemm, 2015). Tujuan utama dari promosi kesehatan yaitu perubahan perilaku. Program duta hand hygiene diharapkan dapat meningkatkan perilaku dalam melakukan hand hygiene yang dapat mencegah penularan antara pasien, petugas kesehatan dan pengunjung.

Hand hygiene adalah istilah umum yang mengacu pada tindakan pembersihan tangan lima waktu atau biasa disebut five moment hand hygiene di fasilitas pelayanan kesehatan yaitu pada saat sebelum kontak dengan pasien, sebelum prosedur bersih atau aseptik, setelah prosedur terpapar cairan tubuh, setelah kontak dengan pasien dan setelah kontak dengan area sekitar pasien (WHO, 2009b). Penerapan hand hygiene merupakan tindakan pencegahan yang terbukti efektif dan sederhana untuk diimplementasikan(WHO, 2009b). Permenkes nomer 27 tahun 2017 tentang pencegahan dan pengendalian infeksi di pelayanan fasilitas kesehatan menyebutkan, kebersihan tangan merupakan salah satu kewaspadaan standar yang harus diterapkan secara rutin dalam perawatan seluruh pasien di 
rumah sakit (Kementerian Kesehatan RI, 2017). Peningkatan motivasi petugas berhubungan dengan kepatuhan dalam mencuci tangan (Sani and Pratiwi, 2017). Motivasi adalah konsep yang digunakan untuk menjelaskan atau memberikan alasan seseorang melakukan sesuatu (Spector and Park, 2018).

Motivasi dapat meningkat melalui promosi kesehatan seperti strategi yang dilakukan oleh Rumah Sakit Islam (RSI) Jemursari untuk meningkatkan angka kepatuhan hand hygiene petugas dengan mengadakan program Duta Hand Hygiene. Pembentukan perilaku dapat dilakukan dengan pembiasaan diri sesuai harapan (Maulana, 2009). Salah satu bentuk promosi kesehatan di RSI Jemursari yaitu program duta hand hygiene dilaksanakan setiap hari jumat dan mulai berlangsung sejak bulan agustus 2017 sampai saat ini melalui pemberian informasi dan edukasi cara melakukan cuci tangan, pentingnya cuci tangan dan waktu cuci tangan kepada pasien, pengunjung dan petugas di rumah sakit.

Penelitian ini bertujuan untuk mengetahui efektifitas adanya kegiatan duta hand hygiene dengan melihat perbedaan angka kepatuhan five moment hand hygiene petugas rumah sakit sebelum dan selama diberlakukan kegiatan duta hand hygiene serta strategi yang diterapkan untuk keberhasilan program menggunakan strategi multimodal WHO dalam peningkatan hand hygiene di RSI Jemursari Surabaya. Variabel yang diukur yaitu angka kepatuhan hand hygiene petugas meliputi unit rawat jalan, kamar operasi, rawat inap, IGD, Hemodialisa, seluruh staf penunjang medis dan staf yang tidak terlibat langsung terhadap pelayanan.

\section{METODE}

Penelitian ini menggunakan metode pendekatan kuantitatif. Data yang digunakan yaitu data sekunder dan data primer. Teknik pengumpulan data dengan telaah dokumen, wawancara, dan observasi. Data sekunder terkait kepatuhan five moment hand hygiene petugas diperoleh dari laporan monitoring bulanan Komite PPI RSI Jemursari mulai dari bulan Januari 2017 sampai Februari 2018 yaitu sebelum dan selama program duta hand hygiene berlangsung. Penelitian analisis data sekunder yaitu penelitian menggunakan pengumpulan data sekunder yang diperoleh dari database instansi, dokumen data statistik, laporan hasil penelitian (Dachi, 2017) atau dengan kata lain data yang sudah tersedia dalam sistem recording atau reporting suatu institusi (Ryadi, 2016).

Selain data sekunder juga menggunakan data primer dengan wawancara dan observasi. Wawancara dilakukan kepada komite PPI dan observasi untuk mengetahui proses berjalannya program duta hand hygiene dan strategi untuk keberhasilan program. Observasi bertujuan untuk membandingakan teori dan kenyataan dilapangan. Peneliti juga berpartisipasi dalam beberapa kegiatan seperti mengikuti kegiatan program duta hand hygiene, perhitungan angka kepatuhan petugas terkait hand hygiene, dan pertemuan rutin komite PPI. Penelitian ini dilakukan di RSI Jemursari Surabaya pada bulan Februari 2018. Teknik analisis data yang digunakan menggunakan uji paired $t$ test. Analisis data dalam penelitian ini menggunakan Confident Interval (Cl) sebesar $95 \%$. Uji t-test digunakan untuk melihat perbedaan sebelum dan sesudah intervensi.

\section{HASIL DAN PEMBAHASAN}

\section{Gambaran Umum RSI Jemursari Surabaya}

Rumah Sakit Islam Jemursari merupakan salah satu unit usaha di bawah Yayasan Rumah Sakit Islam Surabaya yang dibangun pada tahun 1992 dan mengawali operasionalnya pada tanggal 25 Mei 2002 yang ditandai dengan soft opening. Rumah Sakit Islam Jemursari merupakan pengembangan dari Rumah Sakit Islam Surabaya A. Yani dan sekarang berlokasi di Jalan Jemursari nomor 51 - 57 Surabaya dengan luas 4,6 Ha. Rumah Sakit Islam Jemursari merupakan rumah sakit tipe $B$ sejak tahun 2011 yang ditetapkan oleh Kementerian Kesehatan dan telah mendapat sertifikat akreditasi rumah sakit lulus tingkat paripurna di tahun 2016. Visi RSI Jemursari yaitu "Menjadi RS Islam yang terdepan dan terpercaya dalam pelayanan, pendidikan dan penelitian". RSI Jemursari memiliki beberapa pelayanan unggulan seperti bina rohani dan hemodialisis. 


\section{Gambaran Umum Program Duta Hand Hygiene}

Duta hand hygiene adalah duta yang dibentuk oleh Komite Pencegahan dan Pengendalian Infeksi atau Komite PPI Rumah Sakit Islam Jemursari melalui pemilihan duta hand hygiene yang dilakukan pada 22 Juli 2017. Duta hand hygiene beranggotakan enam staf RSI Jemursari dengan komposisi tiga staf medis dari keperawatan dan tiga staf non medis. Pelaksanaan Duta hand hygiene bersama IPCN (Infection Prevention and Control Nurse) yang dilakukan setiap hari jumat di area pasien dan area perkantoran atau administrasi rumah sakit dimulai pukul 08-00-10.00 WIB.

Berikut Kutipan dari majalah yang diterbitkan RSI Jemursari yaitu Caring for your Health Edisi Oktober-Desember 2017:

"Acara tersebut berlangsung 22 Juli lalu. Nama Kegiatannya adalah lomba kreativitas hand hygiene dan pemilihan duta hand hygiene. Selain itu, juga dipilih enam orang sebagai duta hand hygiene. Tiga Perawat, tiga lainnya dari non keperawatan. Tugas mereka dikatakan tidak ringan. Seminggu sekali mereka keliling $R S$ Islam Jemursari untuk sosialisasi cara cuci tangan yang baik dan benar".

Setiap satu tahun sekali akan dilakukan pemilihan untuk pergantian petugas Duta Hand Hygiene sehingga terjadi pembaharuan personil. Hasil observasi menunjukkan bahwa proses promosi kesehatan hand hygiene dilakukan di dalam gedung yaitu di ruang pendaftaran atau administrasi, poliklinik, rawat inap, penunjang medik dan area perkantoran. Pelaksanaan promosi kesehatan berdasarkan peluang dikategorikan di dalam gedung dan di luar gedung menurut Permenkes Nomor 004 Tahun 2012 Tentang Petunjuk Teknis Promosi Kesehatan Rumah Sakit (Kementerian Kesehatan RI, 2012).

\section{Perbandingan Angka Kepatuhan Hand Hygiene Petugas}

Angka kepatuhan hand hygiene adalah angka yang didapat dari hasil audit yang dilakukan oleh staf rumah sakit yang telah mendapat pelatihan dan dilaporkan kepada Komite PPI setiap bulan. Perbandingan angka kepatuhan hand hygiene sebelum dan selama program berlangsung dapat dilihat pada Gambar 1 .

Gambar 1 menunjukkan angka kepatuhan five moment hand hygiene petugas mengalami peningkatan selama program berlangsung dibandingkan sebelum progam duta hand hygiene diterapkan. Peningkatan kepatuhan petugas rata-rata sebesar $7,93 \%$. Peningkatan paling tinggi yaitu pada moment lima atau setelah kontak dengan area sekitar pasien dengan peningkatan sebesar $10,33 \%$.

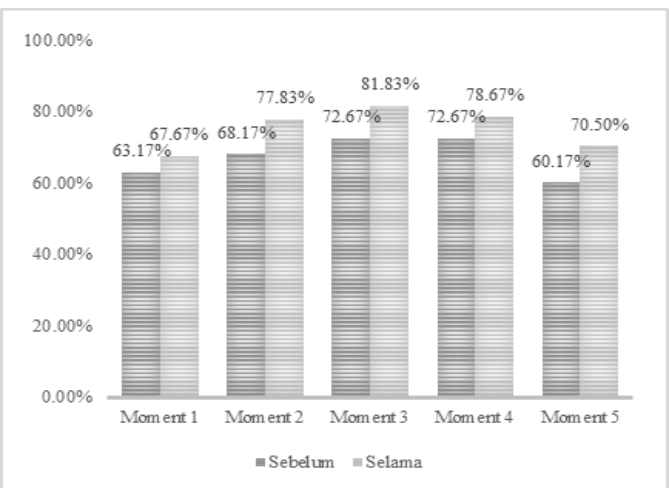

Gambar 1. Perbandingan kepatuhan petugas sebelum dan selama program duta hand hygiene berlangsung

Target angka kepatuhan hand hygine yaitu $80 \%$ yang dihitung setiap bulan. Rumus perhitungan angka kepatuhan hand hygiene sebagai berikut:

Kepatuhan $\mathrm{HH}=\frac{\mathrm{N} 1}{\mathrm{~N} 2} \times 100 \%$

Keterangan:

$\mathrm{HH}=$ Hand Hygiene

$\mathrm{N} 1$ = Jumlah cuci tangan (rub + wash)

$\mathrm{N} 2=$ Jumlah opportunity atau kesempatan melakukan lima waktu cuci tangan.

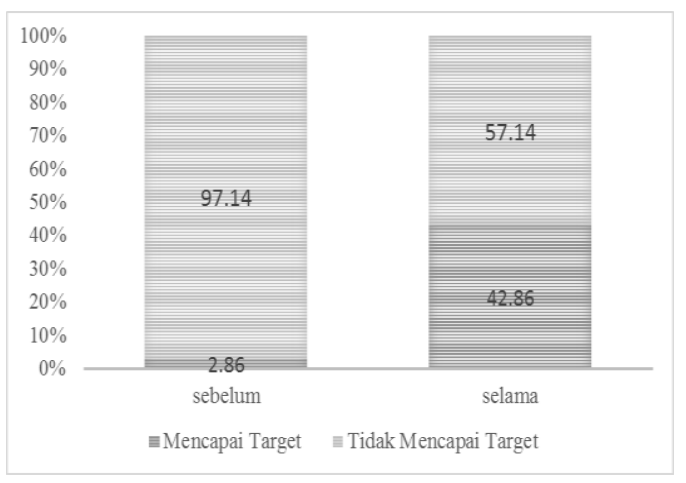


Gambar 2. Perbandingan pencapaian target hand hygiene petugas sebelum dan selama program duta hand hygiene berlangsung

Gambar 2 menunjukkan bahwa terdapat peningkatan pencapain target kepatuhan hand hygiene petugas sebelum dan selama program duta hand hygiene berlangsung yaitu sebesar $40 \%$. Sebelum diberlakukan program hanya $2,83 \%$ petugas yang mencapai target dan selama program berjalan meningkat menjadi $42,86 \%$.

Hasil wawancara kepada IPCN menunjukkan bahwa pengisian audit cuci tangan dilakukan oleh petugas yang telah dilatih oleh Komite PPI. Cara atau prosedur pengisian lembar audit cuci tangan antara lain:

1. Petugas (observer) melakukan pengisian identitas yang terdiri dari nama unit, tanggal, observer dan jam pada saat observasi.

2. Petugas melakukan observasi kepada rekan kerja satu unit yang dipilih secara random dan menuliskan profesi yang di observasi.

3. Setiap lembar observasi memuat empat orang yang akan diobservasi dan lima kesempatan pada setiap profesi.

4. Petugas melakukan pengisian lembar audit cuci tangan dengan melihat kesempatan pada lima momen cuci tangan yang dimiliki oleh profesi yang di observer.

5. Pada kesempatan lima momen cuci tangan akan dilihat apakah profesi yang diobservasi melakukan cuci tangan dengan sabun atau handrub atau tidak mencuci tangan atau menggunakan sarung tangan.

6. Tindakan cuci tangan bisa dengan handrub atau air mengalir, jika tidak dilakukan ketika diindikasikan, harus dicatat sebagai "Tidak".

7. Suatu tindakan cuci tangan yang diamati tidak sesuai dengan indikasi yang sebenarnya tidak boleh dicatat.

Monitoring kepatuhan cuci tangan dapat terlaksana secara rutin setiap bulan. Audit cuci tangan dapat terlaksana dengan baik ketika terdapat dukungan keterlibatan kepala ruangan, adanya supervisi dan pengawasan dengan maksimal (Ernawati, Tri and Wiyanto, 2014).
Perbedaan Kepatuhan Five Moment Hand Hygiene Petugas Sebelum dan Sesudah Program

Uji statistika untuk mengetahui perbedaan kepatuhan hand hygiene sebelum dan selama program dilaksanakan menggunakan uji-t berpasangan. Uji persyaratan analisa sebelum dilakukan uji-t berpasangan yaitu dilakukan dilakukan uji normalitas untuk melihat data berdistribusi normal yang berada pada tabel 1 .

Tabel 1 menunjukkan hasil pengujian normalitas data menggunakan metode Shapiro wilk. Uji normalitas Shapiro wilk digunakan untuk sampel yang sedikit yaitu kurang dari atau sama dengan 50 (Dahlan, 2008). Tabel 1 menunjukkan bahwa data kepatuhan five moment hand hygiene petugas normal dan dapat memenuhi asumsi untuk dilakukan uji paired t-test.

Tabel 1. Hasil Uji Normalitas Data Kepatuhan Hand Hygiene.

\begin{tabular}{clll}
\hline Kepatuhan & & $P$ value & Ket. \\
\hline \multirow{2}{*}{ Moment 1 1} & Sebelum & 0,552 & Normal \\
& Selama & 0,141 & Normal \\
Moment 2 & Sebelum & 0,328 & Normal \\
& Selama & 0,564 & Normal \\
Moment 3 & Sebelum & 0,54 & Normal \\
& Selama & 0,954 & Normal \\
& Sebelum & 0,597 & Normal \\
Moment 4 & Selama & 0,253 & Normal \\
Moment 5 & Sebelum & 0,224 & Normal \\
& Selama & 0,452 & Normal \\
All Moment & & 0.106 & Normal \\
\hline
\end{tabular}

Tabel 2. Hasil Uji Paired Sample T-test Kepatuhan Five Moment Hand Hygiene.

\begin{tabular}{lll}
\hline Kepatuhan & $P$ value & Keterangan \\
\hline Moment 1 & 0,230 & Tidak Signifikan \\
Moment 2 & 0,041 & Signifikan \\
Moment 3 & 0,005 & Signifikan \\
Moment 4 & 0,032 & Signifikan \\
Moment 5 & 0,013 & Signifikan \\
All Moment & 0.000001 & Signifikan \\
\hline
\end{tabular}

Tabel 2 menunjukkan bahwa terdapat perbedaan kepatuhan pada momen dua sampai lima sebelum dan selama program duta hand hygiene berlangsung yang artinya terdapat peningkatan kepatuhan petugas dalam melakukan hand hygiene. Hanya momen satu yaitu sebelum kontak dengan pasien yang tidak menunjukan signifikansi atau perbedaan. Penelitian yang dilakukan di Rumah Sakit Kathmandu Medical Coolage di Wallingford USA mengatakan bahwa 
mayoritas petugas kesehatan melakukan praktik hand hygiene setelah perawatan pasien daripada sebelum melakukan perawatan pasien (Joshi et al., 2013). Faktor yang dapat menghambat petugas melakukan hand hygiene yaitu kurangnya pengetahuan dan teknik hand hygiene, kesibukan yang tinggi dan akses terhadap fasilitas hand hygiene (Ananingsih and Rosa, 2016). Selain itu, faktor yang dapat menghambat kepatuhan pelaksanaan hand hygiene yaitu pasien yang terlalu banyak, memiliki anggapan terhadap resiko infeksi dan lupa melakukan hand hygiene (Wulandari and Sholikah, 2017).

\section{Efektivitas Program Duta Hand Hygiene}

Keberhasilan suatu program dalam melakukan promosi kesehatan tidak lepas dari dukungan rumah sakit. Peningkatan kepatuhan hand hygiene petugas merupakan hasil komitmen manajemen dalam mendukung keberhasilan program duta hand hygiene. Strategi multimodal untuk meningkatkan pelaksanaan hand hygiene antara lain adanya perubahan sistem, pelatihan atau edukasi, evaluasi dan umpan balik, pengingat di tempat kerja dan iklim situsional yang aman (WHO, 2009a). Penerapan strategi multimodal WHO dapat meningkatkankan kepatuhan dan pengetahuan petugas kesehatan secara signifikan di berbagai negara (Allegranzi et al., 2013). Penelitian sebelumnya menyebutkan faktor yang paling mempengaruhi kepatuhan hand hygiene perawat di UGD yaitu pengetahuan, fasilitas, dan pengingat (Pratama, Koeswo and Rokhmad, 2015).

Perubahan sistem yaitu terkait infrastruktur yang diperlukan untuk mendukung petugas kesehatan melakukan hand hygiene seperti adanya akses terhadap ketersediaan air, sabun dan handuk serta handrub berbasis alkohol di titik perawatan. Pelatihan dan edukasi secara rutin tentang pentingnya lima momen hand hygiene dengan prosedur yang benar kepada semua petugas kesehatan. Evaluasi dan umpan balik yaitu adanya pemantauan praktik hand hygiene dan infrastruktur dengan memberikan umpan balik. Pengingat di tempat kerja bertujuan untuk mendorong dan mengingatkan petugas kesehatan tentang pentingnya kebersihan tangan dengan indikasi dan prosedur yang tepat dan menggunakan media yang sesuai. Strategi yang terakhir yaitu menciptakan iklim institusional yang aman dengan memprioritaskan praktik hand hygiene di tempat kerja yang meingkatkan kesadaran individu dan organisasi untuk berubah dan melakukan kemitraan dengan pasien.

Strategi multimodal WHO yaitu perubahan sistem, edukasi, evaluasi dan umpan balik, pengingat di tempat kerja dan Iklim institusional yang aman ditambah dengan kontes atau lomba tingkat organisasi dapat meningkatkan kepatuhan praktek hand hygiene pada tenaga kesehatan di rumah sakit (Sakihama et al., 2015). Penerapan lima strategi multimodal WHO yang efektif dan adanya penetapan tujuan, hadiah, insentif dan strategi yang akuntabilitas dapat meningkatkan praktik hand hygiene petugas kesehatan (Luangasanatip et al., 2015). Promosi kesehatan akan berjalan efektif jika kegiatan tersebut memasukan berbagai metode yang mendorong keterlibatan dan partisipasi dari masyarakat umum (Maulana, 2009). Lima strategi berdasarkan WHO dan implementasi di RSI Jemursari berada pada Tabel 3.

Hasil observasi pada Tabel 3 menjelaskan bahwa RSI Jemursari telah menerapkan $76,47 \%$ indikator strategi WHO. Indikator yang belum terlaksana yaitu penyediaan alcohol based handrub portable, evaluasi dengan memantau konsumsi handrub berbasis alkohol, memberikan penghargaan kepada petugas kesehatan yang memiliki kepatuhan hand hygiene tertinggi dan komunikasi elektronik.

\section{Perubahan Sistem}

Perubahan sistem merupakan komponen penting di semua fasilitas pelayanan kesehatan. Fasilitas pelayanan kesehatan memiliki infrastruktur yang diperlukan untuk memungkinkan petugas kesehatan dalam melakukan hand hygiene. Praktik hand hygiene memungkinkan untuk dilakukan jika terdapat infrastruktur yang memadai. Tujuan dari promosi kesehatan yaitu mengubah perilaku, mengupayakan perubahan lingkungan, sistem dan kebijakan kesehatan (Maulana, 2009). Adanya sarana yang mendukung yaitu ketersediaan fasilitas cuci tangan dapat meningkatkan kepatuhan petugas seperti penelitian sebelumnya terdapat hubungan 
antara fasilitas dan kepatuhan cuci tangan petugas (Dewi, 2017).

Infrastruktur yang mendukung seperti tersedianya keran untuk cuci tangan di setiap ruangan, penempatan handrub di setiap pintu masuk kamar dan ruangan pasien, serta handrub alkohol portabel yang dimiliki setiap petugas kesehatan (Sakihama et al., 2015). Setiap titik perawatan terdapat alcohol based handrub yang siap untuk dipakai oleh petugas, pasien maupun pengunjung. Titik perawatan yaitu tempat dimana terdapat pasien, petugas kesehatan dan lingkungan yang terlibat kontak dengan pasien (WHO, 2009b). Selain alcohol based handrub juga tersedia westafel, air bersih yang mengalir dan sabun antiseptik.

\section{Pelatihan atau edukasi}

\section{Edukasi bertujuan}

untuk meningkatkan pengetahuan, mengubah sikap dan mengarahkan kepada perilaku yang diinginkan (Maulana, 2009). Upaya untuk meningkatkan kepatuhan hand hygiene yaitu edukasi yang berkelanjutan dan melakukan orientasi ulang kepada petugas kesehatan (Uneke et al., 2014). Pendidikan terkait hand hygiene di RSI Jemursari dilakukan

secara berkesinambungan selain program duta hand hygiene yang dilakukan hari jumat juga dilakukan edukasi di tiap unit setiap ada rapat ruangan dan setiap ada orientasi pegawai dan mahasiswa baru. Pendidikan yang efektif dapat meningkatkan pengetahuan, sikap dan praktik petugas kesehatan terkait hand hygiene (Maher, Eslami and Alimohammadzadeh, 2018).

Edukasi merupakan penentu keberhasilan dalam melakukan praktik hand hygiene. Semua petugas pelayanan kesehatan melakukan pelatihan atau edukasi pentingnya hand hygiene dengan pendekatan dan prosedur yang benar. Edukasi bertujuan untuk menginduksi perubahan perilaku dan budaya. Edukasi juga dilakukan terhadap pasien dan keluarga pasien atau pengunjung. Edukasi dan pemberdayaan pasien melakukan hand hygiene memiliki dampak positif terhadap kepatuhan hand hygiene petugas kesehatan (Ahmed Awaji and Al-Surimi, 2016). Mengedukasi pasien tentang pentingnya melakukan hand hygiene mendorong pasien untuk bertanya pada kepada petugas kesehatan terkait praktik hand

hygiene.

Tabel 3. Hasil Observasi Penerapan Strategi Peningkatan Praktik Hand Hygiene di RSI Jemursari Tahun 2018

\begin{tabular}{|c|c|c|}
\hline \multirow{2}{*}{$\begin{array}{c}\text { Strategi } \\
\text { Perubahan Sistem }\end{array}$} & \multicolumn{2}{|c|}{ Penerapan } \\
\hline & lya & $\begin{array}{c}\text { Tida } \\
\mathbf{k}\end{array}$ \\
\hline 1. Westafel cuci tangan di setiap ruangan & S & \\
\hline 2. Penempatan hand rub di setiap titik perawatan & 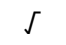 & \\
\hline $\begin{array}{l}\text { 3. Handrub portable berbasis alcohol yang didistribusikan untuk setiap } \\
\text { petugas kesehatan }\end{array}$ & & r \\
\hline \multicolumn{3}{|l|}{ Pelatihan atau edukasi } \\
\hline 4. Ketersediaan Sumber daya dalam melakukan edukasi terkait hand hygiene & S & \\
\hline 5. Seminar atau ceramah secara berkala terkait hand hygiene & L & \\
\hline \multicolumn{3}{|l|}{ Evaluasi dan umpan balik } \\
\hline 6. Evaluasi hand hygiene dengan observasi langsung & J & \\
\hline $\begin{array}{l}\text { 7. Evaluasi hand hygiene dengan dengan memamantau konsumsi handrub } \\
\text { berbasis alkohol }\end{array}$ & & 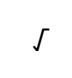 \\
\hline 8. Tanggapan atau umpan balik oleh Komite PPI & J & \\
\hline 9. Tanggapan atau umpan balik oleh unit yang bersangkutan & 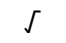 & \\
\hline $\begin{array}{l}\text { 10. Memberikan penghargaan kepada petugas kesehatan yang memiliki } \\
\text { kepatuhan hand hygiene yang paling tinggi }\end{array}$ & & 厂 \\
\hline \multicolumn{3}{|l|}{ Pengingat di tempat kerja } \\
\hline 11. Media cetak & J & \\
\hline 12. Pengingat lisan & S & \\
\hline 13. Komunikasi elektronik & & L \\
\hline 14. Metode lain & S & \\
\hline \multicolumn{3}{|l|}{ Iklim institusional yang aman } \\
\hline 15. Komitmen Direktur Rumah Sakit & J & \\
\hline 16. Komitmen Kepala unit & S & \\
\hline 17. Pertemuan rutin tingkat unit & L & \\
\hline
\end{tabular}




\section{Evaluasi dan umpan balik}

Perilaku sehat sebagai hasil dari suatu promosi kesehatan harus berlangsung terus menerus dan berkesinambungan (Maulana, 2009). Evaluasi merupakan komponen penting dari kegiatan promosi kesehatan yang harus dilakukan dengan integritas yang baik. Evaluasi bertujuan untuk melihat keberlangsungan perilaku yang diharapkan. Evaluasi dan pemantauan ulang berbagai indikator sebagai langkah penting mengidentifikasi dan memberikan informasi untuk melakukan perencanaan.

Evaluasi terhadap praktik hand hygeine dapat dilakukan dengan pengamatan langsung, memantau jumlah pengguaan alcohol base handrub dan menetapkan sistem untuk menilai tingkat kepatuhan praktik hand hygiene (Sakihama et al., 2015). Pengamatan langsung yang dilaksanakan di RSI Jemursari terhadap kepatuhan petugas kesehatan digunakan untuk melihat kepatuhan hand hygiene petugas.

Evaluasi sebagai konsistensi, berkelanjutan, pengumpulan dan analisis informasi untuk pengambilan keputusan yang terbagi menjadi dua tipe yaitu evaluasi formatif dan sumatif (Wells, 2007). Evaluasi formatif yaitu evaluasi yang dimulai pada awal suatu program dan digunakan untuk membuat keputusan tentang perubahan atau peningkatan salaam pelaksanaan program. Evaluasi formatif biasanya dilakukan setiap bulan atau trimester yang melaporkan terkait pertemuan evaluasi program, menyelesaikan kegiatan program dan mengukur kinerja sumber daya manusia. Evaluasi sumatif berupa pengumpulan informasi keseluruhan program tetapi hasil yang digunakan untuk menilai keberhasilan dampak program berdasarkan tujuan dan sasaran yang ditetapkan. Evaluasi sumatif didasarkan pada evaluasi formatif dan follow up data. Evaluasi formatif terhadap kepatuhan hand hygiene petugas dilakukan setiap bulan pada pertemuan rutin Komite PPI. Evaluasi juga dilakukan pada akhir tahun. Laporan Evaluasi Program PPI tahun 2017 menyebutkan bahwa tindak lanjut dari pemilihan duta hand hygiene yaitu pemilihan duta hand hygiene dilakukan secara rutin tiap satu tahun.

Penghargaan yang diberikan kepada petugas kesehatan yang memiliki kepatuhan praktik hand hygiene memang belum diterapan, namun penghargaan kepada unit yang melakukan kepatuhan praktik pencegahan dan pengendalian infeksi yang paling baik secara keseluruhan mendapat penghargaan, penghargaan tersebut berdasarkan penilaian monitoring yang dilakukan oleh Komite PPI.

\section{Pengingat di tempat kerja}

Pengingat di tempat kerja adalah sarana untuk menginformasikan kepada petugas, pasien, dan pengunjung tentang praktik hand hygiene. Pengingat di tempat kerja bertujuan untuk memicu dan mengingatkan petugas kesehatan. Poster adalah sistem pengingat yang paling umum digunakan. Jenis pengingat lainnya yaitu stiker dan brosur. Pengingat harus digunakan dan ditampilkan dan harus diperbarui secara teratur.

Solusi untuk mengingkatkan kepatuhan hand hygiene petugas salah satunya menggunakan sistem pengingat (Uneke et al., 2014). Program duta hand hygiene berfungsi sebagai pengingat untuk melakukan cuci tangan tidak hanya kepada petugas rumah sakit namun juga kepada pasien dan pengunjung. Pengingat ditempat kerja bertujuan untuk mendorong dan mengingatkan petugas kesehatan tentang pentingnya cuci tangan dengan indikasi dan prosedur yang tepat dalam melakukannya (WHO, 2009b).

Pengingat di tempat kerja dapat berupa media cetak, pengingat lisan, media elektronik dan lainnya. Media cetak dapat berupa leaflet, poster, buklet, selembaran, rubrik dan lainnya. Media elektronik dapat berupa penyampaian melalui televisi atau radio. Media yang digunakan dalam program duta hand hygiene yaitu poster sebagai media cetak, pengingat lisan dan metode lain yaitu melalui lagu enam langkah cuci tangan. Duta hand hygiene memperagakan enam langkah cuci tangan dan memberikan informasi terkait waktu melakukan cuci tangan. Sosialiasi poster, pelatihan dan simulasi dapat meningkatkan kepatuhan five moment hand hygiene petugas (Ananingsih and Rosa, 2016). Paparan media cetak juga berhubungan dengan praktik hand hygiene penunggu pasien di rumah sakit (Canti, Husodo and Mustofa, 2016).

Duta hand hygiene menggunakan lagu anak-anak dalam mempraktikan enam 
langkah cuci tangan. Lirik lagu enam langkah cuci tangan dengan menggunakan handrub berbasis alkohol dinyanyikan dengan latar lagu anak-anak yaitu lagu naik becak:

\author{
"Ratakanlah hand rubnya, \\ gosok punggung tangannya, \\ kaitkan keduanya, \\ kunci dua tangannya, \\ putar-putar jempolnya, \\ putar ujung jarinya, \\ cuci tangan bebas dari kuman 2x."
}

Lagu enam langkah cuci tangan di atas telah sesuai berdasarkan langkah cuci tangan WHO yaitu menuangkan handrub berbasis alkohol untuk dapat mencakup seluruh permukaan tangan dan jari, mengosok punggung dan sela-sela jari tangan kiri dengan tangan kanan dan sebaliknya, menggosok kedua telapak dan sela-sela jari, jari-jari sisi dalam dari kedua tangan saling mengunci, menggosok ibu jari kiri berputar dalam genggaman tangan kanan dan lakukan sebaliknya dan mengosok dengan memutar ujung jari-jari ditelapak tangan kiri dan sebaliknya.

\section{Iklim institusional yang aman}

Iklim institusional yang aman bertujuan untuk menciptakan lingkungan yang membawa pada peningkatan kesadaran tentang keselamatan di tempat kerja. Pada tingkat organisasi, komponen dari hand hygiene harus tertanam sebagai budaya organisasi. Pada tingkat individu berhubungan dengan advokasi kepada semua petugas di pelayanan kesehatan untuk melakukan praktik hand hygiene dengan optimal sebagai tindakan yang menunjukan komitmen untuk tidak membahayakan petugas dan pasien. Iklim situsional yang kurang dapat menyebabkan proses pekerjaan menjadi rentan dan berisiko membahayakan kesehatan petugas (Ribeiro et al., 2012). Penciptaan iklim keselamaan organisasi harus menjadi prioritas untuk promosi kesehatan terkait hand hygiene.

Dukungan manajemen terhadap

Duta Hand Hygiene yaitu adanya penetapan SK Direktur anggota program sehingga tidak mengganggu pekerjaan utama di rumah sakit. Hambatan program Duta Hand Hygiene yaitu petugas Duta hand hygiene yang seharusnya dapat berjalan sendiri namun masih perlu pendampingan dari IPCN dan seringnya ketidaklengkapan anggota tim pada program berlangsung yang disebabkan berbagai alasan. Komite PPI dalam melakukan penyeleksian anggota duta hand hygiene perlu melihat kriteria tambahan seperti siap melakukan tugas dan tanggung jawab yang diberikan kepadanya beserta konsekuensinya, izin ketidakhadiran ditetapkan oleh kebijakan dari komite PPI dan mampu bekerja dalam tim untuk menyelasaikan hambatan yang terjadi.

Proses promosi kesehatan akan lebih efektif apabila melibatkan sasaran secara langsung yaitu dengan ikut menyumbangkan gagasan dalam pencarian solusi untuk program kesehatan dan dilakukan secara berkelanjutan (Sassen, 2018). RSI Jemursari melibatkan seluruh petugas rumah sakit untuk mengikuti pemilihan Duta Hand Hygiene melalui lomba hand hygiene yang rutin dilakukan setiap satu tahun sekali. Pada lomba tersebut juga menghasilkan media promosi kesehatan yang digunakan seperti lagu enam langkah cuci tangan dan juga program Duta hand hygiene yang berjalan saat ini dilakukan secara rutin dan berkelanjutan.

Upaya untuk meningkatkan praktik hand hygiene dapat dilakukan dengan mengadakan pelatihan terpusat, menambah jumlah dispenser handrub, memberikan handrub kepada semua petugas, meningkatkan fungsi PPI dan pengawas, menambah poster pengingat dan pemeriksaan koloni bakteri pada tangan petugas yang sering dan jarang melakukan hand hygiene (Pratama, Koeswo and Rokhmad, 2015).

\section{SIMPULAN}

Angka praktik hand hygiene di RSI Jemursari Surabaya sebelum dan selama diberlakukan program Duta hand hygiene menunjukan hasil perbedaan yang bermakna secara statistik. Perbedaan tersebut menunjukan peningkatan kepatuhan hand hygiene pada momen dua sampai lima hanya momen satu yang tidak ada perbedaan.

Duta Hand Hygiene ditujukan untuk melakukan proses promosi kesehatan di lingkungan rumah sakit secara rutin. Program ini efektif dilakukan dan pelaksanaanya didukung strategi multimodal WHO untuk 
peningkatan praktik hand hygiene yaitu perubahan sistem, pelatihan atau edukasi, evaluasi dan umpan balik, pengingat di tempat kerja dan iklim institusional yang aman.

\section{DAFTAR PUSTAKA}

Ahmed Awaji, M. and Al-Surimi, K. (2016) 'Promoting the role of patients in improving hand hygiene compliance amongst health care workers', BMJ Quality Improvement Programme, 5. doi: 10.1136/bmjquality.u210787.w43 36.

Allegranzi, B. et al. (2013) 'Global implementation of WHO's multimodal strategy for improvement of hand hygiene: A quasi-experimental study', The Lancet Infectious Diseases, 13(10), pp. 843-851. doi: 10.1016/S1473-3099(13)70163-4.

Ananingsih, P. D. and Rosa, E. M. (2016) 'Kepatuhan 5 Momen Hand Hygiene Pada Petugas Di Laboratorium Klinik Cito Yogyakarta', Jurnal Medicoetcolegal dan Manajemen Rumah Sakit, 5(1), pp. 16-24. doi: 10.18196/jmmr.5102.

Blackwell, W. (2017) Hand Hygiene: A Handbook for Medical Profesionals. West Sussex: John Wiley \& Sons, Ltd.

Canti, P. R., Husodo, B. T. and Mustofa, S. . (2016) 'Hubungan Paparan Media Informasi terhadap Praktik Han Hygiene pada Penunggu Pasien di Instalasi Rawat Inap RSUD Dr. Adhyatma Tugurejo Kota Semarang', Jurnal Kesehatan Masyarakat (e-Journal), 4(5), pp. 370-378.

Dachi, R. A. (2017) 'Proses dan Analisis Kebijakan Kesehatan: Suatu Pendekatan Konseptual', in. Yogyakarta: Deepublish.

Dahlan, M. S. (2008) 'Statistik untuk Kedokteran dan Kesehatan', in. Jakarta: Salemba Medika.

Dewi, R. R. K. (2017) 'Faktor Determinan Kepatuhan Perawat dalam Melakukan Praktik Cuci Tangan di RSUD Ade Muhammad Djoen Sintang', Jurnal Kesehatan Masyarakat Khatulistiwa, 4(3), pp. 222-237. Available at: http: / /openjurnal.unmuhpnk.ac.i $\mathrm{d} /$ index.php/JKMK/article/view/8 65.

Ernawati, E., Tri, A. R. and Wiyanto, S. (2014) 'Penerapan Hand Hygiene Perawat di Ruang Rawat Inap Rumah Sakit', Jurnal Kedokteran Brawijaya, 28(Supplemen No.1), pp. 89-94.

Joshi, S. et al. (2013) 'Hand Washing Practice Among Health Care Workers in Teaching Hospital', Journal of Nepal Health Research Council, 11(23), pp. 1-5.

Kementerian Kesehatan RI (2012) Peraturan Menteri Kesehatan Republik Indonesia Nomor 004 Tahun 2012 Tentang Petunjuk Teknis Promosi Kesehatan Rumah Sakit. Jakarta: Kementerian Kesehatan RI.

Kementerian Kesehatan RI (2017) Peraturan Menteri Kesehatan Nomor 27 Tahun 2017 Tentang Pedoman Pencegahan dan Pengendalian Infeksi di Fasilitas Pelayanan Kesehatan. Jakarta: Kementerian Kesehatan RI.

Kemm, J. (2015) Health Promotion: Ideology, Discipline, and Specialism. 1st Editio. New York: Oxford University Press.

Luangasanatip, N. et al. (2015) 'Comparative efficacy of interventions to promote hand hygiene in hospital: Systematic review and network metaanalysis', BMJ (Online), 351, pp. 1-14. doi: 10.1136/bmj.h3728.

Maher, A., Eslami, Z. and Alimohammadzadeh, K. (2018) 'Effect of Hand Hygiene Education on Knowledge, Attitude and Practice of NICU and Pediatric Staff in Zanjan Hospitals', Academic Journal of Research in Economics and Management, 3.

Maulana, H. . (2009) Promosi Kesehatan. Jakarta: EGC.

Pratama, B. S., Koeswo, M. and Rokhmad, K. (2015) 'Faktor Determinan Kepatuhan Pelaksanaan Hand Hygiene pada Perawat IGD RSUD dr. Iskak Tulungagung', Jurnal Kedokteran Brawijaya, 28(Supplemen No.2), pp. 195-199. doi: 10.21776/ub.jkb.2015.028.02.14.

Ribeiro, P. et al. (2012) 'Organizational 
214 Jurnal Promkes: The Indonesian Journal of Health promotion and Health Education Vol. 7 No. 2 Desember 2019 : 204 - 214, doi: 10.20473/jpk.V7.12.2019.204-214

safety climate and adherence to standard precautions among dentists', Acta Paulista de Enfermagem, 26, pp. 192-197. doi: $10.1590 / \mathrm{S} 0103$ 21002013000200014.

Ryadi, A. L. . (2016) Ilmu Kesehatan Masyarakat. Edisi Pert. Yogyakarta: CV. Andi Offset.

Sakihama, T. et al. (2015) 'Improving healthcare worker hand hygiene adherence before patient contact: A multimodal intervention of hand hygiene practice in Three Japanese tertiary care centers', Journal of Hospital Medicine, 11, p. n/an/a. doi: 10.1002/jhm.2491.

Sani, F. and Pratiwi, M. (2017) 'HUBUNGAN MOTIVASI PERAWAT DENGAN TINGKAT KEPATUHAN MELAKUKAN CUCI TANGAN DI RSI KLATEN', Profesi (Profesional Islam): Media Publikasi Penelitian, 14, p. 11. doi: 10.26576/profesi.146.

Sassen, B. (2018) Nursing: Health Education and Improving Patient Self-Management. Cham: Springer International Publishing.

Shahida, S. et al. (2016) 'Hospital Acquired Infections in Low and Middle Income Countries: Root Cause Analysis and the Development of Infection Control Practices in Bangladesh', Open Journal of Obstetrics and
Gynecology, 06, pp. 28-39. doi: 10.4236/ojog.2016.61004.

Spector, J. M. and Park, S. W. (2018) Motivation, Learning and Technology: Embodied Educational Motivation. New York: Routledge.

Uneke, C. J. et al. (2014) 'Promotion of hand hygiene strengthening initiative in a Nigerian teaching hospital: Implication for improved patient safety in low-income health facilities', Brazilian Journal of Infectious Diseases, 18(1), pp. 21-27. doi: 10.1016/j.bjid.2013.04.006.

Wells, M. . (2007) Granwriting Beyond the Basics: Successful Program Evaluation. Oregon: Continung Aducation Press.

WHO (2009a) Guide to Implementation: A Guide to Impelementation of the WHO Multimodal Hand Hygiene Improvement Strategy. Geneva: World Health Organization.

WHO (2009b) WHO Guidelines on Hand Hygiene in Health Care: a Summary. Geneva: World Health Organization.

Wulandari, R. and Sholikah, S. (2017) 'Pengetahuan Dan Penerapan Five Moments Cuci Tangan Perawat Di Rsud Sukoharjo', Gaster | Jurnal Ilmu Kesehatan, XV(1), pp. 18-27. Available at: jurnal.stikesaisyiyah.ac.id/index.php/gaster/a rticle/viewFile/133/125. 